\title{
Reconciliation as the functional integration of complex systems
}

\author{
A S van Niekerk \\ (University of Pretoria)
}

\section{ABSTRACT \\ Reconciliation as the functional integration of complex systems}

Reconciliation is usually seen in connection with the relationships between God and his people, and the mutual relationships between people, especially believers in Christ. In Col 1, however, Paul relates reconciliation to all things in heaven and on earth. The implications of this statement for the life and work of the church and her members need further reflection. In this article, attention is given to the dysfunctional interactions between socio-cultural, ecological, economical, political and other systems in the Southern African context. These dysfunctional interactions cause widespread poverty, ecological degradation and social disruption. Church members can see it as their calling to work for the functional integration of these systems, in their own lifestyles as well as in society in general, in order to promote the wellbeing of society.

\section{INTRODUCTION}

In Col 1:19-20 Paul makes a statement about reconciliation and peace that goes infinitely beyond our capabilities to either understand or execute ourselves: "For God was pleased to have all his fullness dwell in him (Jesus Christ), and through him to reconcile to himself all things, whether things on earth or things in heaven, by making peace through his blood, shed on the cross" (NIV).

The peace and reconciliation brought about in South Africa in the nineties, between socio-political forces that had previously been described with terms such as an unstoppable force versus an immovable wall, can be seen - by Christians with faith, love and hope as an event where this reconciling work of God became manifest in history. The role of Christians in the reconciliation process is one indication of this. Desmond Tutu's reference to the miracles that occurred during the hearings of the Truth and Reconciliation Commission is another. 
An alternative interpretation of what has happened is also possible. Christians with a keen sense of justice and of human nature (as Paul says in Rom 3:12, there is no one that does good, not even one) may say with Ecclesiastes that what we thought was something new, had been there before and will happen again. In the alternative interpretation, reconciliation will be seen as a pact between opposing elites, to the benefit of both. It will be seen as the re-alignment of the rich and the powerful, in which the weak and the poor have again been sidelined.

The alternative interpretation can refer to statistics that indicate that there are two important shifts in the income profile in South Africa: firstly, both the rich and the poor are becoming increasingly multiracial, and secondly, the rich are becoming richer and the poor poorer (cf. Whiteford and van Sevenster's study Winners and Losers).

Only the future can reveal which of the two interpretations of the reconciliation process is the most valid. What we can say at this stage is that there are presently exceptional opportunities to carry the existing process of reconciliation through into areas of the South African reality where it is still lacking.

In this article attention is given to the unfinished task to strive, as followers of Jesus Christ, for the reconciliation of all things in Southern Africa to God, through the cross.

There is a qualitative difference between the reconciliation of all things in society (South Africa is a secular state) and the reconciliation of all things in the lives of Christians, who have been reconciled to God through faith in Christ. To what extent this is indeed the case in actual practice, is difficult to say. The divisions that are discussed below are found both in society and in the Christian community. Attention will, at the end, be given to the way in which the Christian community can, from our side, influence society.

Firstly, a number of polarities in Southern Africa are discussed that, it seems, have not been reconciled to each other. These polarities do not represent neatly separated categories. They overlap and interact with each other in ever-changing patterns. But they can be used as a tool for analysing the complex dynamics of our situation. They indicate that it is not sufficient to interpret the problem - the lack of 
reconciliation - in socio-political terms only, but that a holistic problem definition is needed. The existing polarities include the following (not listed according to priority):

\section{THE MISUSE OF TECHNOLOGY}

Genesis 2:46-3:24 can be read as a metaphor of human life: God created us to live close to Himself and to each other in love, and to control or manage his creation and care for it. What Adam and Eve did is, however, repeated every day by all of us: we corrupt our relationship to God with guilt and fear; to each other with blame; to the animals with enmity and to nature with thorns and thistles and joyless labour. These corrupt relationships lead to death, because life depends on and exists in good relations. Jesus is the Way and the Life. To follow in his footsteps, is to fill the spaces between ourselves and others - and ourselves and creation - with love, care and service (Deist 1991:62-64).

Technology plays a decisive role in the way we do so, or fail to do so.

Technology is the totality of means and knowledge used by us to sustain ourselves. Technology increases our power, both our muscle power and our brainpower. It multiplies our ability to move, communicate, produce and destroy. We can use technology to care for each other and for creation, and we can exploit it only for our own personal victories. The choice for us today is essentially the same as it was for Adam and Eve. It appears that we are no wiser or better than they were. We don't choose life. Or rather, we choose short-term benefits and disregard the bigger context.

Through our misuse of technology we consume and waste creation at a pace that raises real fears of global warming, water scarcity, dangerous levels of pollution, desertification, etc. Personal victories lead to global calamities. The huge technology gap in society is also found amongst the members of the DRC-family. Some have knowledge and means that make them very powerful. Others have next to nothing, except their numbers.

Not only is there an unreconciled gap between the technologically powerful and powerless, but also between both groups and creation. Both groups destroy nature - one group by high levels of wasteful consumption, the other by unsustainable subsistence strategies. 


\section{A RIFT BETWEEN SCIENCE AND POLITICS}

By the year 2000, there was general agreement in the international scientific community that the MIV-virus causes AIDS. In that same year President Thabo Mbeki convened an international panel of experts on HIV/AIDS and STD's. Several AIDS-dissidents were included. The Panel was expressly asked to look into the issue "whether there's this thing called AIDS, what it is, whether HIV leads to AIDS, whether there is something called HIV, for example” (Jones 2001:28).

This formed part of an escalating conflict in which harsh words were exchanged between government and a number of academics both black and white.

The government blamed academics and other critics of racism, of being in the pockets of large pharmaceutical companies intent on profits, of being in denial about HIV/AIDS, even of "intellectual intimidation and terrorism" (Mbeki). The presidential spokesperson, Parks Mankahlana, claimed that "the problem that the science world has is this: It has to do with human arrogance” (Jones 2001:27-30,32).

The academics, on the other hand, blamed government of blatantly distorting the truth, of intolerance, lack of moral and intellectual integrity, heavy-handedness, "irresponsibility that borders on criminality" (Mamphela Ramphele), of crazy, dangerous logic, emotional and irrational” (M Makgoba) (Jones 2001:28-30).

Jones (2001:26) states that "government actions and inactions... fostered growing rifts between government, the scientific community, non-governmental organisations (NGOs) and the labour movement”. These rifts have not been reconciled yet.

The government probably deserves most of the criticism levelled against it concerning HIV/AIDS. The heading of the chapter from which the above quotations come, poses a valid question: "Does the South African government care?” That is a question that many health care officials ask.

But that does not mean that scientists have no part in the breakdown of communication with government. Do scientists care? Science has traditionally been based on the exclusion of emotion. It has 
in many ways been alienated from society - in the West, and even more so in Africa. This statement is discussed in the next section.

\section{THE GAP BETWEEN MODERN SCIENCE AND THE AFRICAN WORLD}

Modern science has changed our relationship to nature in ways that cannot be turned back. One can indeed speak of a scientific revolution since the time of the European Renaissance. Modern science has been remarkably successful in unlocking the secrets of nature and in utilising the potentialities of nature. But the results have not been positive in all respects, especially for nature. "A triumph of human reason turned into a sad truth. It seemed that science debased everything it touched" (Prigogine and Stengers 1984:6):

"The cultural tension associated with classical science can be held at least partly responsible for the unstable position of science within society... Let us take an earlier example: the irrationalist movement in Germany in the 1920s that formed the cultural background to quantum mechanics. In opposition to science, which was identified with concepts such as causality, determinism, reductionism, and rationality, there was a violent upsurge of ideas denied by science but seen as the embodiment of the fundamental irrationality of nature. Life, destiny, freedom, and spontaneity thus became manifestations of a shadowy underworld impenetrable to reason. Without going into the peculiar socio-political context to which it owned its vehement nature, we can state that this rejection illustrates the risks associated with classical science”.

The position of science in African society is even more unstable and than in the West, and so are the risks associated with it. From early on, African writers have pointed out that the rationalism of Western culture - also of Western missionaries - was alien to the African experience. Political and religious resistance by Africans to Western rationalism can be traced back to early in the twentieth century (cf Van Niekerk and Pauw 2000).

African writers have repeatedly pointed out that there are important differences between modern Western and African thought patterns.

The philosopher K C Anyanwu (1984:87-93) wrote: 
"The unity of the self and the world, mind and matter, is something magical because it defies any rational understanding. We can only say that the self and the world interpenetrate each other in such a way that we do not know where the self begins and ends for the world to begin... the West seeks rational causality in all things. What happens if nature is alive, if spirit permeates the whole universe, if consciousness cannot grasp the factors of causality? Effects would then be interpreted as magical and so also the method... Magic raises up the question of causality... the whole truth about cause is magical, that is, it belongs to the non-material world" (Anyanwu 1984, 8793).

The literary scholar Ibe Nwoga $(1976: 17,18,21)$ wrote:

"My understanding of the issue is related to a distinction between modes of knowing - that whereas traditional western man has evolved a more detached, analytical mode of understanding of his world, environment and aspects of human functioning, traditional African man retained a more holistic, instinctive mode of understanding... I try various expressions to describe this mode spiritual absorption, instinctive perception of whole meaning, sensitive interaction - but these are words that have their meaning in the language of a cultural mode of perception which is particular and rationalistic. The total of these expressions, however, comes close to what I mean, for which the word rapport may be used... (if) the African should be found to have a predominating tendency towards this type of knowledge, then it should be recognised, not indeed as exclusive, but as characteristic".

The writer and literary scholar Wole Soyinka (1976:viii), who afterwards became a Nobel Prize laureate, pleaded for an academic approach that could express Africans' "true self-apprehension":

"...the apprehension of a culture whose reference points are taken from within the culture itself... African academia has created a deified aura around... intellectualism (knowledge and exposition of the reference points of colonial cultures). To the truly selfapprehending entity within the African world reality, this amounts to intellectual bondage and self-betrayal”. 
In the 1920s the church leader Isaiah Shembe broke away from the missionary churches in search of an own identity. One of his motives was the suppression of oral traditions by the epistemological and cognitive authority of the Western tradition of print (Brown 1998:124).

In the seventies, resistance against white domination became much more political and overt. Black Consciousness, with its slogan: Black is beautiful! was popularised. Political activism often included strong resistance to literate forms. The affirmation of African cultural traditions and the desire to avoid white interference and censorship led to a strategy of performance rather than publication. Poets like Sipho Sepamla and Wally Serote who did publish were regarded "with hostility and mistrust" in spite of their strong support for Black Consciousness and the struggle against apartheid. Performance included features that are associated with an oral rather than a literary tradition: "African robes, rhythmic movement, facial expression, gesture, intonation, alternating pace of delivery, pauses, and the hypnotic beating of the drums". It involved "a return to the ancestral source”, cyclical construction, parallelism and repetition (Brown 1998:182-185):

\section{EUROPEAN OR AFRICAN RENAISSANCE?}

The "Enlightened Movement" ("Verligte Beweging") among the Afrikaners was one of the most important pioneers of F W de Klerk's speech of 2 February 1990.

There seems to be a mismatch between the Verligte Beweging and important elements in the Black struggle against apartheid. The Verligte Beweging linked up with the principle of Reason that characterised the European Renaissance, rather than with the holistic approach of the African Renaissance.

The Black struggle against apartheid was not only against white political domination, but also against the domination of Western culture. It was as much a search for an authentic African identity as it was a search for political freedom. African writers referred back to Kwameh Nkrumah's "African Personality" and Negritude. In the seventies, terms such as Black Consciousness, Black Power and Black Theology became popular. In the nineties it was concepts such as Ubuntu and African Renaissance. 
The influence of the Verligte Beweging is described in some detail by Willem de Klerk (1991:118-134). Willem is the brother of FW. He was a leading figure in the Verligte Beweging. He rejects a style of leadership in which emotions are dominant. He quotes from the historian Barbara Tuchman's The March of Folly, from Troy to Vietman that was published in 1984: "Rejection of reason is the prime characteristic of folly... When desire disagrees with the judgement of reason, there is a disease of the soul. And when the soul is opposed to knowledge or opinion or reason, which are her natural laws, that I call folly... (De Klerk 1991:144-145, 175). It is somewhat discouraging that Tuchman regards policies that harm self-interest as unreasonable. Don't we need a stronger moral motif than self-interest - even enlightened self-interest - if reconciliation is to succeed?

De Klerk argued that Reason in the South African context demanded that Whites as well as blacks had to change. Whites by getting rid of apartheid. Blacks by changing over from the ideologies of a Marxist-socialist and an African one-party dictatorship to a Western orientation in matters of state (De Klerk 1991:175).

The rejection of reason is indeed folly. But so is ignoring the powerful movements of the collective human spirit that do not conform to the demands of reason. The Verligte Beweging, as product of the European Renaissance, followed the road of pragmatic reason. This approach resonated with powerful enlightened movements in the ANC. In the ANC itself there are Africanists and people who are Western in all respects. The enlightened thinking in the National Party resonated with the enlightened thinking in the ANC, and that made it possible to form a strong moderate alliance that has been able to push the reconciliation process through in spite of the opposition of radical forces on both sides. These forces have been pushed to the sidelines and even underground.

But it would be folly to think that that is enough. Progogine and Stengers's warning that science has allowed the non-rational forces to become powerful by ignoring them, applies even more to the present dispensation in South Africa.

The deficiencies of an approach that merely transfers Western models to our African soil are clearly illustrated in the development 
policies followed after 1994. These policies seem very reasonable and enlightened, but they have a blind spot when it comes to deep and powerful aspects of human nature.

All of the unsolved tensions in the deeper structures of our national culture discussed above have a powerful impact on the visible policies and structures in the country. This can be illustrated with reference to the National Electrification Programme (NEP), and the influential Nedcor-Old Mutual Scenarios of 2001 (Tucker and Scott 1992).

\section{THE MISMATCH BETWEEN THE NATIONAL ELEC- TRIFICATION PROGRAM AND THE POOR}

The NEP is a national programme that was launched in 1991, as the Electrification Drive. The program is huge in all respects. Phase 1 (1994-1999) provided 2.5 million electricity connections at a total cost of about R7 billion. Previously disadvantaged and rural areas as well as schools and clinics without electricity were connected to the national grid. Phase 2 followed in 2000; the target to provide 300000 additional households with electricity every year has to date been achieved.

The Electrification Drive was based on the assumption that modernisation was the final cultural destination of the whole South Africa population, and that electricity would be the energy carrier of modernisation. Electricity was expected to replace all other energy carriers, as can be seen in Diagram 1.

The expectation that electricity would replace all other energy carriers was based on the strong association between electricity and modernity, and the assumption that Western modernity was the universally desirable culture. This assumption is clearly visible in a policy speech of Mr A Morgan (1992), who became MD of ESKOM (the national utility company responsible for providing electricity) shortly afterwards. According to Morgan, the aim of mass electrification was to modernise the community, with reference to aspects such as:

- Modern communication and the transfer of information;

- Educational upliftment;

- Cleaner air that reduces health and pollution hazards; 
- Technological development, and

- Saving time (500 million person-hours p.a. to collect wood).

The reasoning behind The Electrification Drive is fully set out in the Nedcor-Old Mutual Scenarios (Tucker and Scott, 1992). The close relationship between the Drive and the Scenarios is seen, for example, in that John Maree, chairperson of ESKOM, who wrote the foreword to the Scenarios, was also co-chairperson of Nedcor, who was the cosponsor of the Scenario project.

Apart from modernisation, socio-political stability was also an aim of the Scenarios. It was argued that a successful transformation from apartheid to democracy was dependent on tangible improvements in the conditions of daily life for the masses (Tucker and Scott 1992, 12-20).

Fast political transformation required fast results on the socioeconomic level. The Nedcor-Old Mutual Scenarios proposed a change of gears approach, in the expectation that the economic, social and political structural changes proposed in the Scenarios would bring about the desired economic growth, development and social stability. These proposals are in line with De Klerk's view that Reason requires a Western orientation in matters of state. De Klerk was a member of the scenario team. 


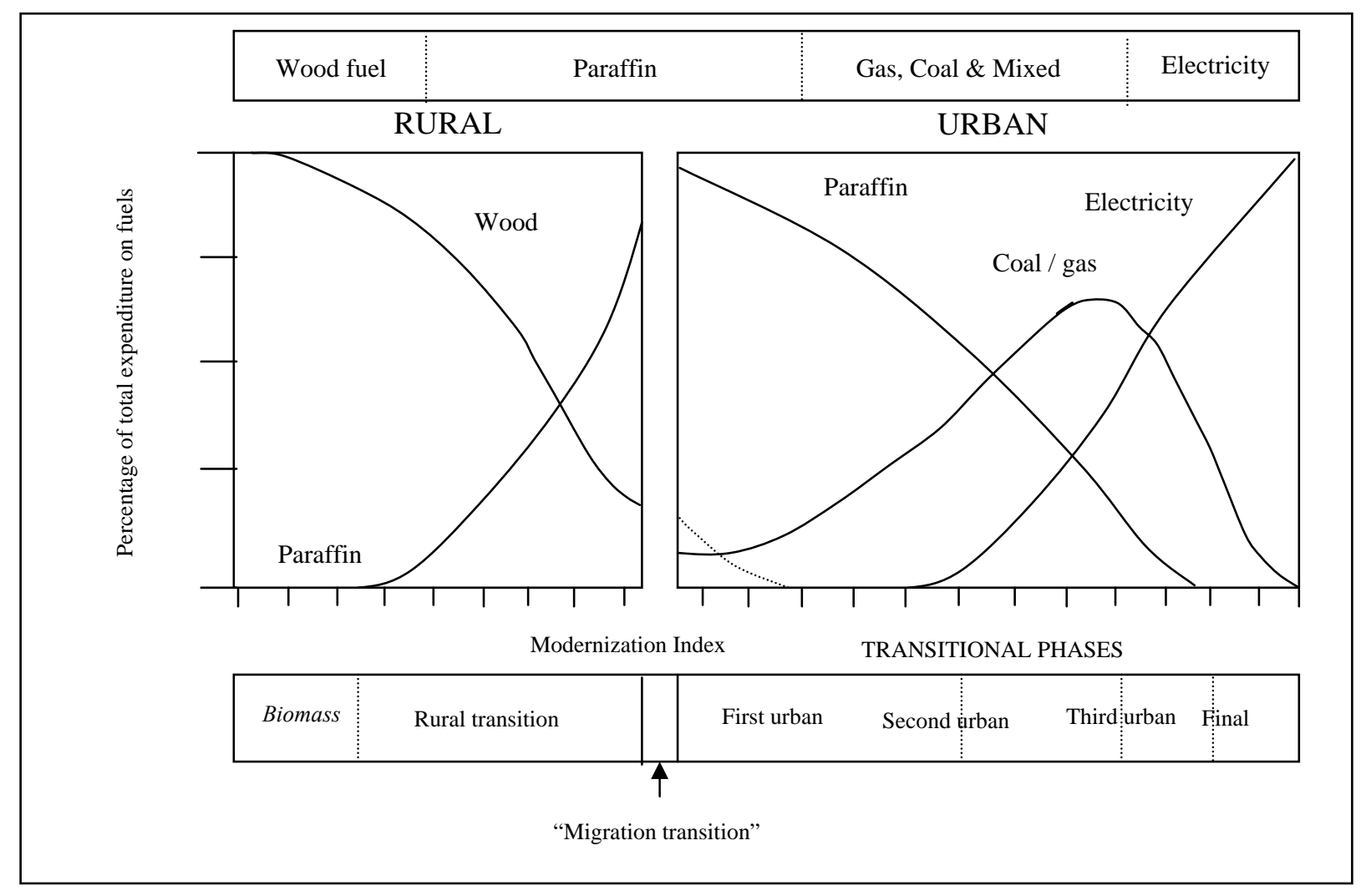

\section{Diagram: The domestic energy transition process in South African black households (Viljoen 1989)}

The Scenarios proposed massive investment in the black community. The approach consisted of a package of key elements such as massive programs for the provision of housing, education, health care and job creation (Tucker and Scott 1992:163).

The results of these programs are complex to evaluate. Education, job creation and the prevention of HIV/AIDS became worse rather than better, according to numerous media reports. Electrification is generally regarded as one of the success stories, but it is not without complications.

On the one hand the benefits of electrification are clear and are highly appreciated by residents. These benefits include safer streets, cleaner houses, opportunities to study at night, etc. The programme contributed to the welfare of the communities by providing improved health care in clinics and evening adult education in schools. Computers and photocopiers where schools could afford them benefited 
education. Fires in homes were reduced because paraffin for lighting and candles were substituted by electricity (Borchers et al 2001).

On the other hand, a number of complications have occurred. The complications occur in relation to both the financial sustainability (cost) and the socio-economic benefits (effectiveness).

The NEP has run into serious problems in terms of financial sustainability. The average consumption in the year 2000 was 132 $\mathrm{kWh} / \mathrm{month} /$ household, while the NEP was initially planned on the assumption and expectation that income would be forthcoming for a consumption level three times higher, estimated at $350 \mathrm{kWh}$. Electricity consumption is so low that revenues in many areas do not cover operation costs (Borchers et al 2001). Case studies show that 56\% of households in South Africa connected to the national grid in Eskomlicensed areas consume less than 50kWh of electricity per month (Prasad \& Ranninger 2003). problem.

Added to this, non-payment for services has been a continuing

The authorities follow a cost recovery policy, which means that consumers are responsible for paying for their services. Since 1994, according to an HSRC study, 10 million people have experienced electricity cuts, 10 million have experienced water cuts, and 2 million people have been evicted from their homes due to the cost recovery policy (McDonald, 2002:162). Many local authorities experience financial difficulties, and the national government has had to subsidise the service. The capacity of ESKOM to continue providing sufficient quantities of power into the future is also an issue that is receiving attention.

The benefits from cooking and heating with electricity were lower than expected because many poor households can only afford to pay for electricity for lighting and media (radio and/or TV).

Electrification may increase expectations and needs - and expenditure - to such an extent that the general feeling of dissatisfaction may eventually increase rather than decrease. The result is a general feeling of alienation, together with the feeling that life has improved. 
The financial loss to authorities caused by mass electrification has to be weighed against the social and developmental gains in the long term.

In conclusion: The Nedcor-Old Mutual Scenarios prescribed policies for a successful transition from apartheid to democracy in South Africa. The conditions for success that have been set out, have not, in general, been met. It is, therefore, understandable that fears have arisen that a new revolution could break out in South Africa (cf Washington Post, as reported in Sake Beeld 12.11.2001, 1).

A scenario is possible to likely, where the business sector can continue to grow by concentrating on capital-intensive, high technology projects that are linked up with the global economy, but more and more isolated from the surrounding masses of poverty-stricken people, struggling with HIV/AIDS, social decay and job losses.

The question is how the different unsolved polarities in our society can be reconciled. A number of - conflicting - strategies are available.

\section{DIFFERENT STRATEGIES TO SOLVE THE TENSIONS}

In this section, a few strategies that have been followed in order to solve the existing tensions are discussed. The lengths to which people would go, and the damage and suffering they would accept as some of these strategies are being implemented. Are an indication how serious these tensions are.

\subsection{The Mugabe option: removing one of the role players}

In 1977 when the struggle against apartheid was on a high level, Mafika Pascal Gwala, a poet from Soweto, wrote:

"Promise you brother,

The cattle shall have herded home

To our ancestral kraal.

Jol'iinkomo!

Africa shall be one in her past.

Jol'iinkomo!

Africa shall have one soul.

Jol'iinkomo!"

(Gwala 1977:70, 71). 
At the beginning of the $21^{\text {st }}$ century, something of this nature is being realised. Robert Mugabe is destroying the modern economy of Zimbabwe, and he enjoys wide support in Africa. This motif, of restoring the relationship with the ancestral spirits, played a decisive role during the war against Ian Smith's minority government (Huizer 1991:29-31).

In 2003 we did fieldwork with theological students in a township near an industrial area. During a group discussion, some of the youth expressed the view that the industries should go, the mines should go, as well as the modern farms and the roads, so that people can again graze their cattle on their ancestral land.

This option does attempt to reconcile some elements of the South African world, but certainly not all things. The restoration of the Africa of the past remains an extremely vague ideal. It does not prevent Mugabe from living the most luxurious life that the modern economy and technology can offer. It happens at a terrible price for the poor, and it excludes all those who are not part of this mythical African past.

\subsection{Expanding the circle, or: the re-unification of all things}

Kofi Awoonor, a writer and literary scholar from Ghana, also wants to restore the unity that was central to the traditional world, but he wants do do so by assimilating the new into the traditional pattern, rather than by eliminating it. In his discussion of Chinua Achebe's famous book “Things fall apart”, he writes (Awoonor 1976a:252, 254):

"To Achebe, the African world before the arrival of Europe was a well-integrated one, with dignity and honour... As a story of the tragic encounter between Africa and Europe, it is an attempt to capture and restate the pristine integrity which has been so traumatically shattered by that confrontation .... Order and coherence are followed by that slow, imperceptible and disguised process of destruction and decay ..... when the Christians come .... the seeds of havoc are planted".

The solution follows the problem definition (Awoonor 1976b:167):

"widening the circle .... ultimately will constitute the only human progress ... the reunification of all things in a primary universal construct”. 
The Afrikaans writer W A de Klerk (not family of the other two) quoted a writer of the Black Consciousness Movement who spoke in similar terms:

"Blackness means widening the circle, absorbing and integrating instead of being absorbed and integrated ... blacks must establish moral and actual authority over the whole" (De Klerk 1979:322).

Discussions of the African Renaissance produce statements in the same vein, such as "a modern African culture" and "modernisation the African way". In this way Africa can take up its proper place in the global community of nations, without being alienated from itself.

\subsection{The Newtonian synthesis}

The failure of modern science to deal adequately with the irrational aspects of human nature has been traced back to the Middle Ages and the Renaissance in Europe.

Modern science is based on the instinctive assumption that each event can be correlated to its antecedents, that each effect has a cause. This assumption inspires scientists to search for causal relations. The assumption originated, according to the philosopher Alfred North Whitehead, in the belief of the Middle Ages, that combined the faith in the personal energy of the Biblical God with the rationality of a Greek philosopher (Prigogine and Stengers 1984:47).

Scientists believed in a God who created an orderly universe, who gave man the task to investigate how this order worked: "An automaton needs an external god". The relation between modern science and Christian faith in this time can be describes with the term "resonance". The result was that "scientists and theologians joined forces to describe nature as a mindless, passive mechanics that was basically alien to freedom and the purposes of the human mind" (Prigogine and Stengers 1984:7, 47, 50).

The Afrikaans theologian J A Heyns was a strong advocate of such an approach. His "Theology of the Kingdom" stated that God has created the world, that he sustains it, and in Jesus Christ saves it. His purpose with creation is expressed in the task that he gave to the first people, male and female, to subdue the earth and rule over it (Gn 1). The final goal of this task can be seen in the last chapters of the Bible, 
where the New Jerusalem is described. History begins with a garden and ends with a city. When practising science and technology - and art, politics, sport, and all other cultural activities - we take part in making God's purpose for history a reality, in many small ways. The secularisation of reality has made science possible; God has created a secular world and has given us the task to investigate and cultivate his creation. Through technology we are not only obeying this command we are in some way already contributing to the new Jerusalem of the future.

Heyns took up the resonance that existed in modern European culture and expressed it in his theology and in his own person. He developed an Afrikaans version of this tradition. He represents a high point in the synthesis of all elements in the Afrikaner culture of the twentieth century: He played a leading role in the church (e.g. as moderator of the General Synod of the Dutch Reformed Church from 19xx-19xx), in the scientific community (e.g. as chairperson of the Akademie van Wetenskap en Kuns), on the cultural terrain (e.g. as chairperson of the Federadsie van Afrikaanse Kultuurverenigings), in politics (e.g. during the negotiations for the end of apartheid and the transfer to the new dispensation) etc. He united all these aspects of life in his own person.

Apartheid can be interpreted as an effort to maintain this cultural tradition - and the lifestyle associated with it - on African soil. Apartheid was sometimes called "separate development". The element of development links up with the development projects that the West has undertaken in Africa. Development can be interpreted as an effort to transfer modern Western culture to Africa, in order to integrate Africa into the global economy.

To what extent the failure of apartheid must be attributed to the course injustices and oppression that increasingly characterised it, and to what extent the vision of a modern Western culture itself has met with resistance, is not clear.

What is clear, is that the synthesis of elements that characterised Afrikaans culture in the twentieth century has disintegrated. Afrikaans culture has become as chaotic as any other in this country. A lot of damage is done in the process. The positive side is that Afrikaans 
culture can now be a role player in the interaction between complex cultural systems. What type of order would emerge out of that is not clear.

\subsection{The functional integration of complex systems}

According to Prigogine and Stengers order can emerge spontaneously out of chaos under certain conditions.

This phenomenon in the natural world may not be applicable to the human world, where the agent of free will and human decision plays a role. But it is not completely without relevance. Progogine and Stengers want to develop a framework in which the natural sciences and the human sciences can be brought into dialogue again.

The search for reconciliation in South Africa needs such a framework in order to be able to analyse the complex interactions between the different cultural and natural systems in the daily lives of people. A reliable grasp of these processes is an essential pre-requisite of designing and constructing products and processes that would promote harmonious interactions. Where the prophetic voice of the church was prominent in the struggle against apartheid, and remains important, there is also a need for Biblical wisdom, in the sense of mastering the practical art of living. Such wisdom would have to make full use of Western science and technology as well as indigenous African knowledge and experience. Reconciliation between people and nature can perhaps take the form of sustainable development and new technology; reconciliation between cultures could perhaps produce a modern African culture and a suitable form of the African Renaissance; theology could perhaps contribute to reconciliation by promoting interdisciplinary synergy in the academic community, and between the scientific community and the poor.

Such a reconciliation process will require thousands and millions of small efforts to functionally integrate those aspects of the South African world that each one of us are involved in. It would require a tinkering attitude.

\section{Consulted literature}

Anyanwu, K C 1984. In Ruch E A and Anyanwu, K C. African philosophy Rome: Catholic Book Agency. 
Awoonor, K 1976(a). The breast of the earth. New York: Anchor Press.

-, 1976 (b). Tradition and continuity in African literature in Smith, Rowland (ed): Exile and Tradition, London: Longman and Dalhousie Press.

Borchers, M, Qase, N, Gaunt, T, Mavhungu, J, Winkler, H, Afrane-Okese, Y \& Thom, C 2001. National Electrification Programme evaluation: Summary report Evaluation commissioned by the Department of Minerals \& Energy and the Development Bank of Southern Africa. Cape Town, Energy \& Development Research Centre, University of Cape Town.

Brown, D 1998. Voicing the text: South African oral poetry and performance. Oxford University Press: Cape Town.

Deist, F E 1991. Die ewige lewe en die lewe van elke dag (Gen 2:4b - 3:24) in: Vos, C J A and Müller, J (eds). Mens en omgewing, Halfway House: Orion.

De Klerk, W A 1976. The Puritans in Africa. London: Penguin.

De Klerk, W 1991. F $W$ de Klerk. Die man en sy tyd. Cape Town: Tafelberg/Jonathan Ball.

Gwala, P 1977. Jol'iinkomo. Johannesburg: Ad Donker.

Huizer, G 1991. Folk spirituality and liberation in South Africa. Bordeaux: Universite de Nimegue.

Jones, $\mathrm{T}$ T 2001. Who cares? AIDS Review 2001. Pretoria: University of Pretoria.

McDonald, D A 2002. The bell tolls for thee: cost recovery, cutoffs, and the affordability of municipal services in South Africa in: McDonald, David A \& Pape, John (eds). Cost recovery and the crisis of service delivery in South Africa. Cape Town: Human Sciences Research Council Publishers.

Nwoga, D I 1976. The limitations of universal critical criteria in: Smith, R (ed), Exile and tradition. Harare: Zimbabwe.

Prasad, G \& Ranninger, H 2003. The social impact of the basic electricity support tariff (BEST). Domestic use of energy. Cape Town: Cape Technikon, 17-22.

Prigogine, I and Stengers, I, 1984. Order out of chaos. Man's new dialogue with nature. London: Heinemann.

Soyinka, W 1976. Myth, literature and the African world. London: Cambridge University Press.

Tucker, B and Scott, B R (eds) 1992. South Africa: prospects for successful transition. Cape Town: Juta.

Van Niekerk, A and Pauw, C J 2000. Understanding and/or participation? The goal of making the Bible available in an oral context. Scriptura 74, 249-257. 
Viljoen, $\mathrm{R}$ 1989. The domestic energy transition process in the context of rapid urbanization, (MSc Thesis). University of Cape Town.

Whiteford, A \& Van Sevenster, D E 1999. Winners and losers. South Africa's changing income distribution in the 1990s. Pretoria: WEFA. 